\title{
A Gender-Specific Association between the Serotonin Transporter Gene and Suicide Attempts
}

Enrique Baca-García, M.D., Concepción Vaquero, M. Sc., Carmen Diaz-Sastre, M.D., Jeronimo Saiz-Ruiz, M.D., José Fernández-Piqueras, Ph.D., Jose de Leon, M.D.

This pilot study tested the gender-specificity of the association between suicide attempts and a polymorphism in the promoter area of the serotonin transporter with two allelic variants, a long (1) variant and a short (s) variant. In a Spanish general hospital, 180 suicide attempters (121 women and $59 \mathrm{men}$ ) and 212 control blood donors (93 women and 119 men) were recruited. Subjects were classified as $S$ individuals $(s / s$ or $s / l)$ with low expression of the serotonin transporter, and L individuals (l/l) with high expression. $S$ individuals were significantly overrepresented (or $L$, underrepresented) in female attempters when compared with female controls and male attempters. Lethality appeared to have a significant influence on the effects of the genotype in suicide since $S$ females were overrepresented among nonlethal female attempters. Further studies are needed to replicate that the serotonin genotype polymorphism may influence suicide attempts only in females.

[Neuropsychopharmacology 26:692-695, 2002] (C) 2002 American College of Neuropsychopharmacology. Published by Elsevier Science Inc.
KEY WORDS: Serotonin; Suicide; Genetics; Serotonin transporter; Association; Women

Suicide attempts, in more than $90 \%$ of the cases, are associated with mental disorders. Vulnerability to suicide is probably best understood in the context of Mann's model of stress-diathesis (Mann et al. 1999). Low brain serotonergic function appears to be undeniably related to suicidal behavior across different psychiatric diag-

From the Department of Psychiatry, Hospital Ramon y Cajal, Universidad de Alcala-Madrid, Madrid, Spain (EB-G, CD-S, JS-R), Department of Biology, Universidad Autónoma de Madrid, Madrid, Spain (CV, JF-P), Eastern State Hospital, Lexington, KY (JdL).

Address correspondence to: Jose de Leon, M.D., Mental Health Research Center at Eastern State Hospital, 627 West Fourth St., Lexington, KY 40508. Tel.: (859) 246-7487, Fax: (859) 246-7019, E-mail: jdeleon@uky.edu

Received June 29, 2001; revised October 11, 2001; accepted October 15, 2001

Online publication: 10/16/01 at www.acnp.org/citations/ Npp101601187. noses and within specific psychiatric diagnoses (Mann et al. 1999).

Growing evidence indicates that genetic factors contribute to suicide risk. Moreover, familial and adoption studies suggest that it appears to be transmitted as a trait independent of Axis I and II disorders. A recent study suggested that genetic factors account for $45 \%$ of the variance in suicidal behavior, and more importantly can be detected after correcting for psychiatric diagnosis, traumatic events, personality traits, and religious affiliations (Statham et al. 1998).

The serotonin transporter (5-HTT) gene is one of the major genes known to influence serotonergic transmission. It was mapped to the chromosome 17q11.1-q12. In the promoter area, there are two allelic variants, a long (l) variant and a short (s) variant. In vitro studies show that the " 1 " allele has two to three times higher basal transcriptional activity. The " $\mathrm{s}$ " allele acts in a nearly dominant way. Therefore, the subjects are classified as $\mathrm{S}$ individuals (s/s or s/l) or L individuals (l/l) (Lesch 
and Hiels 2000). S individuals appear to have lower serotonergic activity as measured in platelets, a postmortem brain study, a brain imaging study and a cerebrospinal fluid study.

Many studies relating 5-HTT genotype in the promoter area and psychiatric illnesses had been negative; a few were positive but have not been replicated. There are seven published studies relating the 5-HTT genotype with suicide in specific diagnostic groups. Three studies: one on completed suicide (Mann et al. 2000), one on attempted suicide (Geijer et al. 2000), and one on subjects believed to have high risk (Russ et al. 2000) did not show any association. One very small study on completed suicide in depression showed an increase of $\mathrm{L}$ subjects (Du et al. 1999). Three studies showed an increase of S subjects in attempters: one study in completed suicides (Bondy et al. 2000); one study on violent suicide attempts in depressive patients (Bellivier et al. 2000), and another on more lethal attempters in alcoholic patients (Gorwood et al. 2000). No gender differences were explored in any of these studies.

This is a pilot study of the possible association between suicide attempts and the 5-HTT polymorphism in the promoter area. Compared with published studies, this study has two strengths: Patients were recruited from a catchment area of a general hospital and assessed just after the attempt. This study is our third study focused in the specific factors associated to suicide attempts in females (Baca-García et al. 2000). The planned focus on gender-specific genes associated with female suicide is justified by the possible dimorphic nature of the serotonergic system and by the greater number of suicide attempts in females.

\section{METHODS}

\section{Subjects}

Between February 1999 and January 2000, 180 attempters (121 women and 59 men) were recruited. The Hospital Ramon y Cajal triages all emergencies in a catchment area of 500,000 persons in Madrid (Spain); all are Caucasians. This general hospital of the National Health Service provides free medical coverage to the population. Following the definition recommended by $\mathrm{NIH}$, suicide attempts included those attempts with some evidence that the person intended to kill himself/ herself (O'Carroll et al. 1996). Suicide attempters were assessed during the first $24 \mathrm{~h}$ after the attempt. The battery included the Suicide Intent Scale, the Mini International Neuropsychiatric Interview (a brief structured interview for the major Axis I psychiatric disorders in DSM-IV), the International Personality Disorders Examination, the Barrat Impulsivity Scale, and the Lethality Rating Scale (Beck et al. 1974). The lethality scores range between 0 (no consequences) and 8 (death). A score $>2$ suggests a lethal attempt and indicates the need for major medical interventions. Attempts were classified as lethal (19\%) and non-lethal (81\%). The controls included 212 blood donors (93 women and 119 men) from the same hospital, without personal or familial history of suicide attempts or psychiatric disorders. After complete description of the study to the subjects, written informed consent was obtained.

\section{Genotype Determinations}

DNA was extracted from a $10 \mathrm{ml}$ blood sample according to standard methods. Patients and controls were screened by the molecular analysis of a particular insertion/deletion polymorphism in the promoter region of the 5-HTT gene. Target DNA was amplified using the primers and conditions previously described (Heils et al. 1996). Amplified products were resolved in agarose gels and detected by ethidium bromide staining.

\section{RESULTS}

The respective prevalence of $\mathrm{L}$ and $\mathrm{S}$ subjects among controls (32\% and 68\%) was very similar to the published figures among U.S. and European Caucasians (29-34\% and 71-66\%). The genotype frequencies were distributed according to Hardy-Weinberg equilibrium both in controls $\left(\chi^{2}=0.21, \mathrm{df}=1, p=.65\right)$ and patients $\left(\chi^{2}=0.11 ; \mathrm{df}=1, p=.74\right)$.

There was a significant increase of $\mathrm{S}$ females in attempters when compared with female controls (odds ratio, $\mathrm{OR}=2.0$; confidence intervals, $\mathrm{CI}=1.1-3.6 ; p=.02$ see in Table 1). The Armitage test for linear trends was significant $\left(\chi^{2}=4.1 ; \mathrm{df}=1, p=.04\right)$. This trend needs to be verified in larger samples. When comparing $1 / 1 \mathrm{vs.} 1 / \mathrm{s}$ $(\mathrm{OR}=2.0 ; \mathrm{CI}=0.97-3.9)$ or $1 / 1$ vs. $\mathrm{s} / \mathrm{s}(\mathrm{OR}=2.1 ; \mathrm{CI}=$ 0.93-5.0) the increases in suicide attempts were almost significant, but there was no significant difference when comparing s/l vs. s/s $(\mathrm{OR}=1.1 ; \mathrm{CI}=0.52-2.3)$.

The male suicide attempters did not show an increase in the $S$ genotype. There was an almost significant increase of $\mathrm{S}$ (or decrease of $\mathrm{L}$ ) in female attempters versus male attempters $(\mathrm{OR}=1.9, \mathrm{CI}=0.90-3.7$; $p=.07$ see in Table 1 ).

Neither the presence of Axis I or II diagnoses, major depression (the most frequent Axis I diagnosis in females), impulsivity during the attempt, nor impulsivity personality traits as measured by the Barrat Scale had significant influence on the effects of the 5-HTT genotype in suicide. However, lethality appeared to significantly influence the effects of the 5-HTT genotype in suicide. There were $33 \%$ of lethal attempts among $\mathrm{L}$ attempters and $18 \%$ among $\mathrm{S}$ attempters $(\mathrm{OR}=2.2, \mathrm{CI}=$ 0.90-5.4, Fisher's exact test, $p=.086$ ). Either $\mathrm{S}$ individuals were overrepresented in non-lethal female attempt- 
Table 1. L versus S Genotype: Comparison of Frequency Distributions in Suicide Attempters and Controls Using Chisquare Tests

\begin{tabular}{|c|c|c|c|c|}
\hline & S & \multirow{2}{*}{$\frac{\mathrm{L}}{1 / 1}$} & \multirow[b]{2}{*}{ Attempters vs. controls } & \multirow[b]{2}{*}{ Males vs. females } \\
\hline & s/s & & & \\
\hline Male controls & $71 \%(84 / 119)$ & $29 \%(35 / 119)$ & Male: $\chi^{2}=0.37 ; \mathrm{df}=1, p=.54$ & Controls: $\chi^{2}=0.88 ; \mathrm{df}=1, p=.35$ \\
\hline \multirow{2}{*}{$\begin{array}{l}\text { Male suicide } \\
\text { attempters }\end{array}$} & $\begin{array}{c}19 \%(23 / 119) 52 \%(61 / 119) \\
66 \%(39 / 59)\end{array}$ & \multirow{2}{*}{$34 \%(20 / 59)$} & & \multirow{2}{*}{ Attempters: $\chi^{2}=3,21 ; \mathrm{df}=1, p=.07$} \\
\hline & $15 \%(9 / 59) \quad 51 \%(30 / 59)$ & & & \\
\hline \multirow[t]{2}{*}{ Female controls } & $65 \%(60 / 93)$ & \multirow[t]{2}{*}{$35 \%(33 / 93)$} & \multirow[t]{4}{*}{ Female: $\chi^{2}=5.15 ; \mathrm{df}=1, p=.02$} & \\
\hline & $21 \%(19 / 93) \quad 44 \%(41 / 93)$ & & & \\
\hline \multirow{2}{*}{$\begin{array}{l}\text { Female suicide } \\
\text { attempters }\end{array}$} & $79 \%(95 / 121)$ & \multirow[t]{2}{*}{$21 \%(26 / 121)$} & & \\
\hline & $27 \%(32 / 121) \quad 52 \%(63 / 121)$ & & & \\
\hline
\end{tabular}

ers $(89 \%)$ as compared with female controls $(65 \%)$ $(\mathrm{OR}=3.7$, CI 1.7-9.1, Fisher's exact test, $p=.001)$, or L females were underrepresented.

\section{DISCUSSION}

These results suggest a gender-specific association between 5-HTT genotype in the promoter area and suicide attempts. These results in female attempters were obtained in $2 \times 2$ cell analysis so they can be interpreted in two ways: (1) Women attempters with low expression of 5-HTT (S females) may be more vulnerable to suicide than those with high expression of 5-HTT (L females); (2) Women attempters with high expression of 5-HTT (L females) may be more protected from suicidal behavior than those with low expression of 5-HTT ( $\mathrm{S}$ females). If there is a dose effect of $\mathrm{s}$ ( $\mathrm{s} / 1$ intermediate between $s / s$ and $1 / 1)$, it may help determine if $s$ is detrimental or 1 is protective (Table 1). Unfortunately our data did not clearly suggest a dose effect of $s$, and the published physiological data suggests that $\mathrm{s}$ is dominant and s/1 subjects probably have similar expression of 5-HTT as s/s subjects. The data of lethality would suggest that $S$ females may be more prone to attempts, but appear to be more prone only to non-lethal attempts.

Although our results were significant, the number of female attempters with L genotype was relatively small (26 of 121). It is possible that our findings may be explained by population stratification. Further studies in larger and different populations are needed to confirm the implication of the 5-HTT gene in susceptibility to female suicidal attempts.

\section{ACKNOWLEDGMENTS}

This article was partly supported by a 1999 National Alliance for Research on Schizophrenia and Affective Disorders (NAR-
SAD) Young Investigator Award to Enrique Baca-García. The authors thank Margaret T. Susce, R.N., M.L.T. for editorial assistance.

\section{REFERENCES}

Baca-García E, Diaz-Sastre C, de Leon J, Saiz-Ruiz J (2000): The relationship between menstrual cycle phases and suicide attempts. Psychosom Med 62:50-60

Beck AT, Schuyler D, Herman I (1974): Development of suicidal intent scales. In Beck AT, Resnick HLP, Lettiem D, Bowie MD (eds), The Prediction of Suicide. Bowie, Maryland, Charles Press Inc, pp 45-56

Bellivier F, Szoke A, Henry C, Lacoste J, Bottos C, NostenBertrand M, Hardy P, Rouillon F, Launay JM, Laplanche JL, Leboyer M (2000): Possible association between serotonin transporter gene polymorphism and violent suicidal behavior in mood disorders. Biol Psychiatry 48: 319-322

Bondy B, Erfurth A, de Jonge S, Kruger M, Meyer H (2000): Possible association of the short allele of the serotonin transporter promoter gene polymorphism (5-HTTLPR) with violent suicide. Mol Psychiatry 5:193-195

Du L, Faludi G, Palkovits M, Demeter E, Bakish D, Lapierre YD, Sotonyi P, Hrdina PD (1999): Frequency of long allele in serotonin transporter gene is increased in depressed suicide victims. Biol Psychiatry 46:196-201

Geijer T, Frisch A, Persson ML, Wasserman D, Rockah R, Michaelovsky E, Apter A, Jonsson EG, Nothen MM, Weizman A (2000): Search for association between suicide attempt and serotonergic polymorphisms. Psychiatr Genet 10:19-26

Gorwood P, Batel P, Ades J, Hamon M, Boni C (2000): Serotonin transporter gene polymorphisms, alcoholism, and suicidal behavior. Biol Psychiatry 48:259-264

Heils A, Teufel A, Petri S, Stober G, Riederer P, Bengel D, Lesch KP (1996): Allelic variation of human serotonin transporter gene expression. J Neurochem 66:2621-2624

Lesch KP, Hiels A (2000): Sertonergic gene transcription control regions: targets for antidepressant drug development. Int J Neuropsychopharmacology 3:67-79 
Mann JJ, Waternaux C, Gretcher LH, Malone KM (1999): Toward a clinical model of suicidal behavior in psychiatric patients. Am J Psychiatry 156:181-189

Mann JJ, Huang YY, Underwood MD, Kassir SA, Oppenheim S, Kelly TM, Dwork AJ, Arango V (2000): A serotonin transporter gene promoter polymorphism (5-HTTLPR) and prefrontal cortical binding in major depression and suicide. Arch Gen Psychiatry 57:729-738

O'Carroll PW, Berman AL, Maris RW, Moscicki EK, Tanney BL, Silverman M (1996): Beyond the Tower of Babel: a nomenclature for suicidology. Suicide Life Threat Behavior 26:227-235

Russ MJ, Lachman HM, Kashdan T, Saito T, BajmakovicKacila S (2000): Analysis of catechol-O-methyltransferase and 5-hydroxytryptamine transporter polymorphisms in patients at risk for suicide. Psychiatry Res 93:73-78

Statham DJ, Heath AC, Madden PAF, Bucholz KK, Bierut L, Dinwiddie SH, Slutske WS, Dunne P, Martin NG (1998): Suicidal behavior: an epidemiological and genetic study. Psychol Med 28:839-855 